\title{
Colostrum immunoglobulin G concentration of multiparous Jersey cows at first and second milking is associated with parity, colostrum yield, and time of first milking, and can be estimated with Brix refractometry
}

\author{
N. Silva-del-Río, ${ }^{*}{ }^{1}$ D. Rolle, ${ }^{*} \dagger$ A. García-Muñoz,ł S. Rodríguez-Jiménez, ${ }^{\dagger}$ A. Valldecabres, ${ }^{*} \dagger$ A. Lago,§ \\ and P. Pandey†\#ll \\ *Veterinary Medicine Teaching and Research Center, 18830 Road 112, Tulare, CA 93274 \\ †Department of Population Health and Reproduction, School of Veterinary Medicine, University of California, Davis 95616 \\ ¥Facultad de Veterinaria, Universidad CEU Cardenal Herrera, Valencia, Spain 46115 \\ §DairyExperts Inc., Tulare, CA 93274 \\ \#Department of Biological and Agricultural Engineering, and \\ IIDepartment of Land, Air and Water Resources, University of California, Davis 95616
}

\begin{abstract}
The objective of this study was to evaluate colostrum IgG concentration harvested at first and second milking from multiparous Jersey cows, the dam's lactation number, colostrum yield, and time of first milking. In addition, we validated the use of a Brix refractometer to estimate IgG concentration in colostrum from multiparous Jersey cows using radial immunodiffusion as the reference method. Colostrum samples and total weight of colostrum harvested at first $(\mathrm{n}=134)$ and second $(\mathrm{n}=68)$ milking were collected from 134 multiparous Jersey cows housed in a California herd. Fresh colostrum samples were analyzed for $\operatorname{IgG}$ concentration with Brix refractometry and frozen samples by radial immunodiffusion. A total of 90.4 and $42.7 \%$ of the samples from first and second milking met industry standards of quality for IgG concentration $(>50 \mathrm{~g} / \mathrm{L})$. Second and third lactation cows had similar colostrum IgG concentration but lower than cows on their fourth and greater lactation. At second milking, $56.4 \%$ of cows on their fourth or greater lactation had colostrum $\operatorname{IgG}$ concentrations $>50 \mathrm{~g} / \mathrm{L}$. When colostrum yield increased from low $(<3 \mathrm{~kg})$, medium (3 to $6 \mathrm{~kg}$ ), to high ( $>6 \mathrm{~kg}), \operatorname{IgG}$ concentration decreased. Higher IgG concentration was observed on colostrum harvested at $<6 \mathrm{~h}$ (short) versus 6 to $11 \mathrm{~h}$ (medium) after calving. However, IgG concentration in colostrum harvested after $11 \mathrm{~h}$ (long) was similar to that harvested at short and medium time. Readings of \%Brix were highly correlated with $\mathrm{IgG}$ at first $(\mathrm{r}=0.81)$ and second $(\mathrm{r}=0.77)$ milking. The best
\end{abstract}

Received December 2, 2016.

Accepted March 7, 2017.

${ }^{1}$ Corresponding author: nsilvadelrio@ucdavis.edu
Brix threshold to identify colostrum from first milking with > $50 \mathrm{IgG}$ g/L was $20.9 \%$ based on logit equations with Youden's index criterion and $18.0 \%$ based on accuracy criterion. For colostrum harvested at second milking, similar Brix thresholds were obtained, 19.2 and $19.0 \%$, regardless of whether Youden's index or accuracy was used as the selection criterion. Our results indicate that the dam's lactation number, colostrum yield, and time of first milking relative to calving are associated with $\operatorname{IgG}$ concentration in colostrum from multiparous Jersey cows. Second milking colostrum from mature Jersey cows should be evaluated to extend colostrum supply on dairies especially during times of shortage. Readings of \%Brix can be used to rapidly estimate IgG concentration in Jersey colostrum harvested at first and second milking.

Key words: colostrum, Jersey, radial immunodiffusion, Brix refractometry

\section{INTRODUCTION}

Providing newborn calves with adequate IgG supply from colostrum is generally recognized as an essential management practice in calf rearing. Calves that fail to reach serum IgG levels above $10 \mathrm{~g} / \mathrm{L}$ within the first $2 \mathrm{~d}$ of life are considered to undergo failure of passive transfer (FPT; Godden, 2008). Evidence indicates that FPT is a prevalent problem in US dairy herds (Beam et al., 2009). The negative effect of FPT on calf health and production is not limited to a higher mortality and morbidity risk during the pre-weaning period, and detrimental effects have also been shown on feed efficiency and milk yield of mature dams (DeNise et al., 1989; Faber et al., 2005). Economic losses associated with FPT have been estimated to average $\$ 65$ per calf when accounting for calf mortality, morbidity, and decrease in average daily weight gain (Raboisson et al., 2016). 
Industry standards define colostrum as high quality when IgG concentration is greater than $50 \mathrm{~g} / \mathrm{L}$ (Godden, 2008). In a recent survey conducted in 67 herds from 12 states, almost $30 \%$ of maternal colostrum failed to reach IgG concentrations above $50 \mathrm{~g} / \mathrm{L}$ (Morrill et al., 2012). Moreover, in a recent meta-analysis, colostrum IgG concentrations were highly variable within and across studies (Buczinski and Vandeweerd, 2016). Parity, pre-partum diet, season, breed, dry-period length, vaccination of the dam, and delayed colostrum collection are factors associated with colostrum quality that have been previously reviewed (Godden, 2008). Thus, to prevent FPT, it is essential to know the IgG concentration of colostrum and to restrict the first feeding to colostrum that meets the standard of quality.

Radial immunodiffusion (RID) assay is used as a standard method to determine colostral IgG concentration. Specific gravity can be used on the farm to estimate colostral IgG concentration with colostrometers. However, even though colostrometers are relatively inexpensive, their fragility and sensitivity to temperature has limited their adoption on the farm (Quigley et al., 2013). Studies conducted over the last decade, mostly with Holstein colostrum, have shown that \%Brix refractometry can be successfully used to estimate IgG concentration. Suggested Brix readings thresholds range widely across studies, from $18 \%$ (Morrill et al., 2012) to $22 \%$ (Bielmann et al., 2010).

The objectives of this study were to evaluate if IgG concentration in colostrum harvested at first and second milking from multiparous Jersey cows was associated with parity, colostrum yield, and time of first milking relative to calving. Another objective was to validate the use of a Brix refractometer to estimate IgG concentration in colostrum harvested at first and second milking.

\section{MATERIALS AND METHODS}

\section{Study Population}

The study was conducted on a California commercial dairy farm housing 3,500 Jersey dairy cows from January to February 2016. The study herd had an average daily milk production of $23.8 \mathrm{~kg} / \mathrm{d}$. During the close-up period, cows were fed once a day with a corn silagebased TMR prepartum diet with a nutrient composition on a DM basis of $16.3 \% \mathrm{CP}, 26.3 \% \mathrm{ADF}, 1.38 \mathrm{Mcal} / \mathrm{kg}$ of $\mathrm{NE}_{\mathrm{M}}$, and $-17.6 \mathrm{mEq} / 100 \mathrm{~g}$ of DCAD. Twice a day, at noon and at midnight, postpartum cows were moved from the maternity pen to the colostrum pen, where they remained for $4 \mathrm{~d}$. Cows housed in the colostrum pen were milked twice a day at 1500 and at $0300 \mathrm{~h}$ in a double 35-stall herringbone parlor.

\section{Data Collection and Colostrum Storage Process}

Colostrum samples were collected from 134 Jersey cows. Sixty-eight cows were sampled at first and second colostrum milking; 66 cows were sampled only at first milking. Colostrum was harvested according to standard practices at the dairy in individual milking buckets. After each cow was milked, harvested colostrum was transferred into plastic containers that were weighed immediately using a portable scale with a readability of 0 to $50 \mathrm{~kg} \pm 2 \mathrm{~g}$ (Ship-Elite, American Weight Scales Inc., Cumming, GA). Colostrum samples were collected directly from the plastic bucket and transferred into 20-mL plastic vials and transported to the laboratory within $30 \mathrm{~min}$ after collection. Parity records of enrolled cows were obtained from the herd management software DairyComp305 (Valley Ag Software, Tulare, $\mathrm{CA}$ ). During the study period, records of calving time were collected every $6 \mathrm{~h}$ at the maternity pen from maternity record sheets filled out by on-farm employees as part of the dairy management.

\section{Colostrum Evaluation Process}

Upon arrival at the laboratory, fresh colostrum samples were evaluated for \%Brix with a handheld electronic refractometer (Reichert Inc., Depew, NY). Approximately $50 \mu \mathrm{L}$ were placed on the refractometer well for each reading. In between samples, the refractometer was rinsed with distilled water and dry-cleaned with wipes.

Fresh colostrum samples were aliquoted into 5 -mL vials and frozen $\left(-20^{\circ} \mathrm{C}\right)$. At the end of the study collection period, frozen samples were shipped to the California Animal Health Food Safety Laboratory (University of California-Davis) for IgG analysis with the RID kit (Triple J Farms kit, Bellingham, WA).

\section{Categorical Variables}

Lactation Number. Cows were grouped as second, third, and fourth or greater parity. The proportion of cows in each category was $23.1,27.6$, and $49.3 \%$ at first milking, and 19.1, 23.5, and $57.4 \%$ at second milking, respectively.

Colostrum Yield. Colostrum yield was classified as low $(<3 \mathrm{~kg})$, medium ( 3 to $6 \mathrm{~kg})$, and high $(>6 \mathrm{~kg})$. The proportion of cows in each category was $37.0,41.5$, and $21.5 \%$ at first milking, and $32.4,50.7$, and $16.9 \%$ at second milking, respectively.

Time from Calving to First Milking. Time from calving to first milking was classified as short $(<6 \mathrm{~h})$, medium (6 to $11 \mathrm{~h})$, or long $(>11 \mathrm{~h})$. The proportion 
Table 1. Descriptive statistics for first and second milking colostrum collected from multiparous Jersey cows on a dairy farm in California

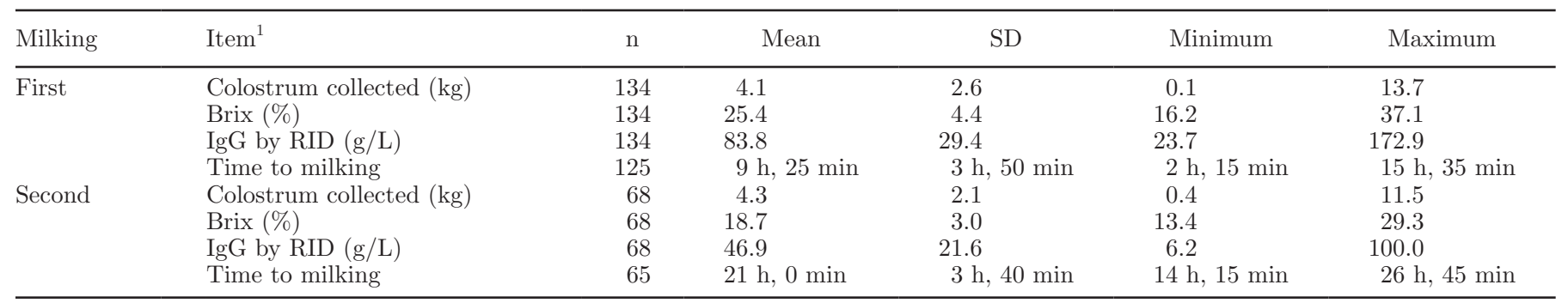

${ }^{1} \mathrm{RID}=$ radial immunodiffusion.

of cows in each category was $25.8,36.3$, and $37.9 \%$, respectively.

\section{Statistical Analysis}

Descriptive statistics were calculated with the MEANS procedures of SAS (version 9.4, SAS Institute Inc., Cary, NC). The 50th percentile (median, $\mathbf{Q}_{2}$ ), 25 th percentile $\left(\mathbf{Q}_{1}\right)$, and 75 th percentile $\left(\mathbf{Q}_{3}\right)$ were computed using the PCTLDEF $=4$ option in the output statement of the UNIVARIATE procedure. The association between IgG concentration with each of the categorical variables (lactation number, colostrum yield, and time from calving to first milking) was evaluated using the GLM procedure of SAS with the LSD option of the means statement. To evaluate the association between \%Brix, IgG, and colostrum yield at first and second milking, Pearson correlation coefficients were calculated with the CORR procedure of SAS.

Data were evaluated for normal distribution using the UNIVARIATE procedure of SAS, including the histogram and normal kernel options. To describe colostrum with at least $50 \mathrm{~g} / \mathrm{L}$, diagnostic test characteristics of Brix refractometry, including sensitivity, specificity, positive predictive value, negative predictive value, and accuracy (samples correctly identified as having adequate or inadequate IgG concentrations by RID), were obtained using the FREQ procedure of SAS for Brix refractometer readings of $18,19,20,21$, and $22 \%$.

To identify the optimal threshold to differentiate colostrum samples with adequate $\operatorname{IgG}$ concentration $(>50 \mathrm{~g} / \mathrm{L})$ at first and second milking using Brix refractometry, receiver operating characteristic analyses were conducted using the OUTROC option of the MODEL statement from the LOGISTIC procedure of SAS. The maximum potential of effectiveness of the Brix refractometer was calculated based on Youden's index $(J)$ criterion (Youden, 1950) from the OUTROC option output as $J=($ sensitivity + specificity -1$)$. The probability that resulted in the highest Youden's index was used to identify the threshold that maximized the correct classification of colostrum samples.

\section{RESULTS AND DISCUSSION}

Descriptive statistics of first and second colostrum milking including colostrum yield, \%Brix, IgG by radial immune diffusion, and time from calving to first and second milking are presented in Table 1.

\section{IgG Concentration in Colostrum}

First and Second Colostrum. At first milking, colostrum IgG concentration averaged $83.8 \mathrm{~g} / \mathrm{L}$ (range: 23.7 to $172.9 \mathrm{~g} / \mathrm{L})$. Most colostrum samples (90.4\%) met industry standards for IgG concentration ( $>50$ $\mathrm{g} / \mathrm{L})$. Prior studies reporting colostrum IgG concentrations in multiparous and primiparous Jersey cows averaged $65.8 \mathrm{~g} / \mathrm{L}$ (Quigley et al., 1994), $66.5 \mathrm{~g} / \mathrm{L}$ (Muller and Ellinger, 1981), $84.5 \mathrm{~g} / \mathrm{L}$ (Quigley et al., 1995), and $72.9 \mathrm{~g} / \mathrm{L}$ (Morrill et al., 2015). Multiple factors including breed, age, dry period length, prepartum diet, and time to colostrum collection are associated with colostrum IgG concentration. However, the relatively elevated IgG concentrations observed in the present work compared with previous reports can be partially explained because only multiparous cows were enrolled in our study. At second milking, colostrum IgG concentrations were lower $(P<0.001)$ than at first milking, averaging $46.9 \mathrm{~g} / \mathrm{L}$ (range: 6.2 to $100 \mathrm{~g} / \mathrm{L}$ ). This was expected, as previous studies reported $\operatorname{IgG}$ concentrations decreased by 78 and $47 \%$ at second and a third milking relative to the first milking (Foley and Otterby, 1978). In our study, nearly half of the second milking colostrum samples $(42.7 \%)$ met industry standards for desirable $\operatorname{IgG}$ concentrations.

Lactation Number. The box plot distribution of IgG concentration by lactation number is shown in Figure 1. The mean $\operatorname{IgG}$ concentration in colostrum from first milking was similar for cows on their second $(77.3 \mathrm{~g} / \mathrm{L})$ and third lactation $(74.9 \mathrm{~g} / \mathrm{L})$ but lower $(P<0.01)$ than for cows on their fourth and greater lactation $(98.4 \mathrm{~g} / \mathrm{L})$. Similar results were observed at second milking: IgG concentration was higher $(P<$ $0.01)$ for cows on their fourth and greater parity $(55.8$ 
$\mathrm{g} / \mathrm{L})$ compared with cows on their second $(39.0 \mathrm{~g} / \mathrm{L})$ and third parity $(38.7 \mathrm{~g} / \mathrm{L})$.

Previous studies have reported increasing $\operatorname{IgG}$ concentration with parity in Norwegian, Guernsey, and Holstein breeds (Tyler et al., 1999; Moore et al., 2005; Gulliksen et al., 2008; Morrill et al., 2012). Accordingly, prior researchers have also reported an increase in IgG concentrations that was most obvious when comparing cows on their first and second lactation with cows with 4 or more lactations (Moore et al., 2005; Gulliksen et al., 2008). In contrast, Quigley et al. (1994) reported lower colostrum IgG in Jersey cows on their second lactation compared with primiparous cows or cows on their third or greater lactation.

It has been hypothesized that the higher colostrum IgG concentration observed in more mature cows could be explained by their longer exposure to antigens (Godden, 2008). Although in our study IgG concentrations were lower in colostrum harvested at second milking, the proportion of samples that met quality standards, especially in multiparous cows on their fourth or greater lactations $(56.4 \%)$, warrants measurements of $\operatorname{IgG}$ on second milking colostrum from mature cows as a viable strategy to extend colostrum supply on dairies with limited availability.

Colostrum Yield. The box plot distribution of $\operatorname{Ig} \mathrm{G}$ concentration by colostrum yield is shown in Figure 2 . Colostrum yield was negatively associated $(P<0.01)$ with $\operatorname{IgG}$ concentration at first $(\mathrm{r}=-0.37)$ and at second $(r=-0.36)$ milking. Likewise, other researchers had reported a significant but weak association between IgG concentration and colostrum yield in Holstein cows (Maunsell et al., 1999; Morin et al., 2010). Concentration of IgG in colostrum decreased as yield increased with $97.7,85.3$, and $71.6 \mathrm{~g} / \mathrm{L}$ at first milking and with $58.5,47.2$, and $34.0 \mathrm{~g} / \mathrm{L}$ at second milking for low, medium, and high production levels, respectively. Pritchett et al. (1991) proposed $8.5 \mathrm{~kg}$ of colostrum as a critical level of production in Holstein cows. In the aforementioned study, cows producing below this threshold point had a greater likelihood of meeting the standards of quality based on colostrum IgG concentration. Other authors have found quantity of colostrum produced at the initial milking is negatively correlated with IgG concentration (Cabral et al., 2016).

Differences in colostrum yield may result in diverse critical levels of production across breeds. Because very few samples failed to meet the standards of quality in our study, we did not try to identify a critical level of production. Nevertheless, at first milking only $25 \%$ of the cows with $\operatorname{IgG}>50 \mathrm{~g} / \mathrm{L}$ produced $>4.9 \mathrm{~kg}$ of colostrum, whereas $75 \%$ of the cows with $\operatorname{IgG}<50 \mathrm{~g} / \mathrm{L}$ produced $>4.3 \mathrm{~kg}$ of colostrum.

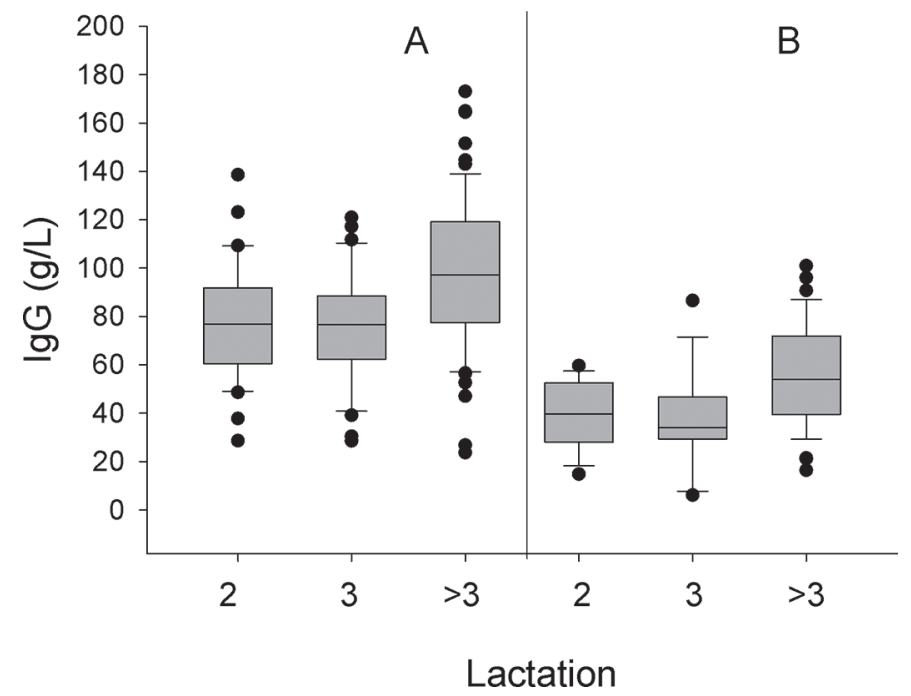

Figure 1. Box plot distribution of colostrum IgG concentration from Jersey cows on their second, third, or >third lactation. Colostrum was harvested at first $(\mathrm{A} ; \mathrm{n}=134)$ and second $(\mathrm{B} ; \mathrm{n}=68)$ milkings. The box plot shows the 50th percentile (median, line within the box), 25 th and 75 th percentile (box), 10th and 90th percentiles (whiskers), and outliers (dots).

Time from Calving to First Milking. Colostrum was harvested at $9 \mathrm{~h}, 25 \mathrm{~min}(\mathrm{SD}=3 \mathrm{~h} 50 \mathrm{~min})$ and at $21 \mathrm{~h}, 0 \mathrm{~min}(\mathrm{SD}=3 \mathrm{~h} 40 \mathrm{~min}$ ) after calving for first and second milking respectively. An effect was observed of milking time relative to calving on colostrum IgG

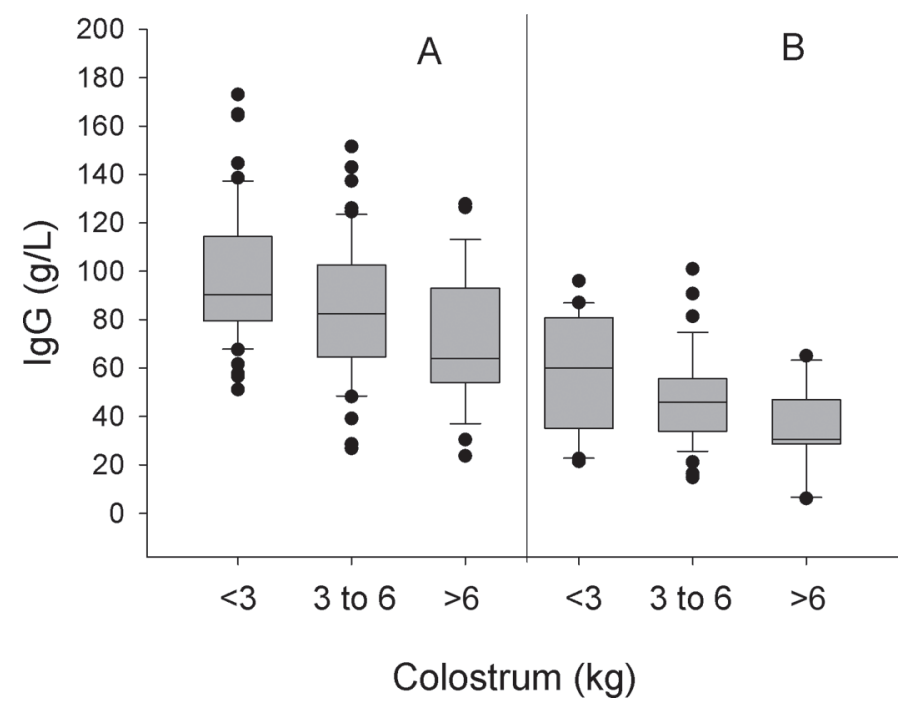

Figure 2. Box plot distribution of colostrum $\operatorname{IgG}$ concentration from multiparous Jersey cows producing low $(<3 \mathrm{~kg})$, medium ( 3 to $6 \mathrm{~kg}$ ), or high $(>6 \mathrm{~kg})$ colostrum. Colostrum was harvested at first $(\mathrm{A} ; \mathrm{n}=134)$ and second $(\mathrm{B} ; \mathrm{n}=68)$ milking. The box plot shows the 50 th percentile (median, line within the box), 25th and 75th percentile (box), 10th and 90th percentiles (whiskers), and outliers (dots). 
concentration. As expected, a higher IgG concentration was observed when time to harvest colostrum was short $(96.7 \mathrm{~g} / \mathrm{L})$ versus medium $(82.1 \mathrm{~g} / \mathrm{L})$. However, when milking time relative to calving was long $(84.1 \mathrm{~g} / \mathrm{L})$, IgG concentration was not statistically different from short or medium time.

Morin et al. (2010) found no association between milking time relative to calving on 81 Holstein cows. In the aforementioned study, cows were milked as soon as 20 min after calving or as late as $23 \mathrm{~h}, 50 \mathrm{~min}$. Similar results were obtained by Cabral et al. (2016) on 111 colostrum samples harvested from $1 \mathrm{~h}$ to $14 \mathrm{~h}, 30 \mathrm{~min}$ after calving. However, Moore et al. (2005) reported a significant effect of milking time relative to calving on 13 cows from which colostrum was harvested from the same quarter exactly at $2 \mathrm{~h}(113 \mathrm{~g} / \mathrm{L}), 6 \mathrm{~h}(94 \mathrm{~g} / \mathrm{L}), 10$ $\mathrm{h}(82 \mathrm{~g} / \mathrm{L})$, and $14 \mathrm{~h}(76 \mathrm{~g} / \mathrm{L})$ after calving. Conneely et al. (2013) studied colostrum quality on 704 samples and reported no changes in quality until colostrum was harvested after 9 to $12 \mathrm{~h}$ after calving.

In our study, management at the dairy resulted in first colostrum always being harvested not earlier than
$2 \mathrm{~h}$ and up to $15 \mathrm{~h}$ after calving. Based in our field experience, most commercial operations in California lack adequate management to harvest colostrum shortly after calving. Some operations even limit first colostrum collection to once a day. Thus, time from calving to first milking might be a management practice to re-evaluate on dairies that have IgG concentration in colostrum below desirable levels.

\section{IgG and \%Brix}

A significant $(P<0.001)$ association was observed between \%Brix and IgG concentration of colostrum at first $(\mathrm{r}=0.81)$ and second $(\mathrm{r}=0.77)$ milking (Figure 3 ) from multiparous cows. Brix readings at first colostrum were $\mathrm{Q}_{1}=22.3 \%, \mathrm{Q}_{2}=25.4 \%$, and $\mathrm{Q}_{3}=28.3 \%$, whereas at second colostrum the readings were $\mathrm{Q}_{1}=$ $17.0 \%, \mathrm{Q}_{2}=18.4 \%$, and $\mathrm{Q}_{3}=19.8 \%$.

Diagnostic test characteristics for 18, 19, 20, 21, and $22 \%$ Brix readings are shown in Table 2. Logit functions were obtained for first milking $[\operatorname{logit}(\mathrm{p})=-20.32$ $( \pm 6.18)-1.06( \pm 0.31) \times$ Brix $]$ and second milking

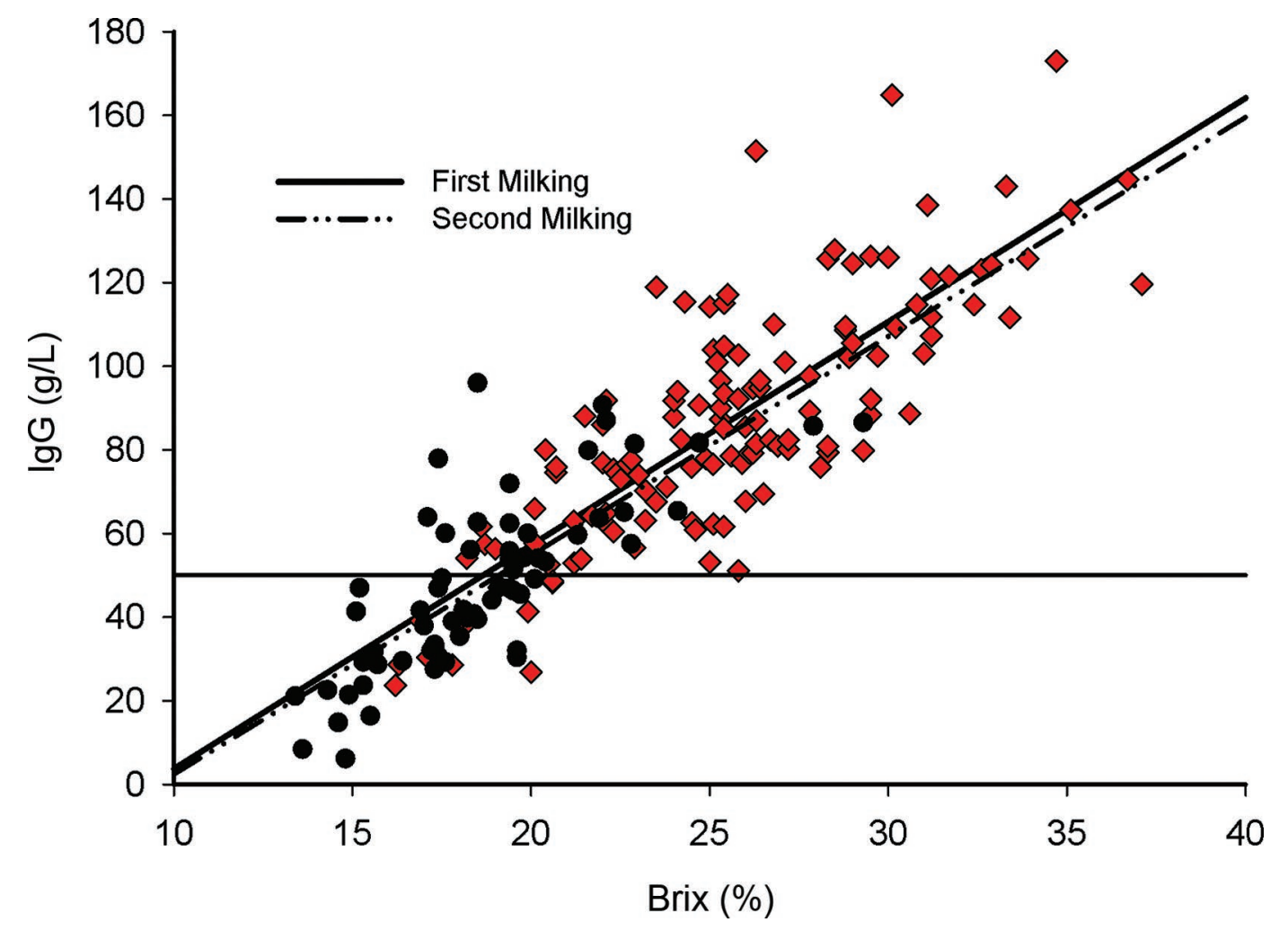

Figure 3. Association between \%Brix readings and IgG concentration by radial immunodiffusion assay from multiparous Jersey colostrum at first (diamonds; $\mathrm{n}=134$ ) and second milking (circles; $\mathrm{n}=68)$. A significant association $(<0.001)$ was observed between IgG $(\mathrm{g} / \mathrm{L})$ and $\mathrm{Brix}$ $(\%)$ : Y $[\operatorname{IgG}(\mathrm{g} / \mathrm{L})$ at first milking $]=-52.4( \pm 5.4)+10.4( \pm 0.4) \times$ Brix at first milking $(\mathrm{r}=0.81) ; \mathrm{Y}[\operatorname{IgG}(\mathrm{g} / \mathrm{L})$ at second milking $]=-49.9$ $( \pm 10.1)+5.2( \pm 0.5) \times$ Brix at second milking $(\mathrm{r}=0.77) ; \mathrm{Y}[\mathrm{IgG}(\mathrm{g} / \mathrm{L})$ at first and second milking $]=-53.3( \pm 5.2)+5.5( \pm 0.2) \times \mathrm{Brix}$ at first and second milking $(\mathrm{r}=0.76)$. Horizontal line indicates $\mathrm{IgG}=50 \mathrm{~g} / \mathrm{L}$. Color version available online. 


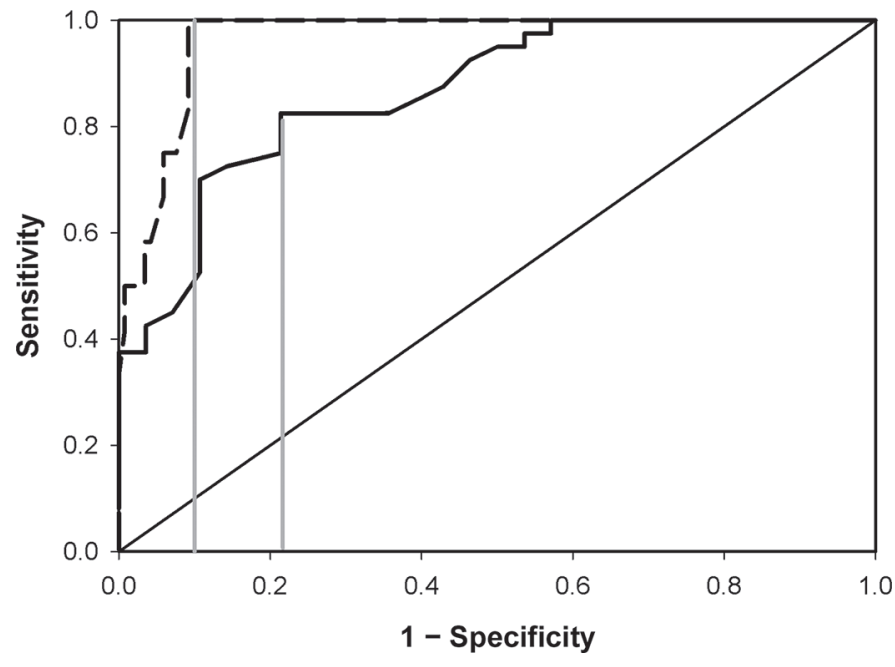

Figure 4. Receiver operating characteristics curves for \% Brix readings of colostrum harvested at first (dashed line; $\mathrm{n}=134$ ) and second milking (solid line; $\mathrm{n}=68$ ) for diagnosis of poor colostrum quality based on IgG concentrations with radial immunodiffusion. The selected threshold based on Youden's index is represented in gray.

$[\operatorname{logit}(\mathrm{p})=-19.80( \pm 5.11)-1.04( \pm 0.27) \times$ Brix $]$ Based on the predicted probabilities obtained from the Youden's index criterion (Youden, 1950) for first $(P=$ $0.13)$ and second milking $(P=0.45)$, the best \% Brix thresholds to predict colostrum with $\operatorname{IgG}>50 \mathrm{~g} / \mathrm{L}$ were $20.9 \%$ (area under the curve $=0.977$ ) and $19.2 \%$ (area under the curve $=0.897$ ) for colostrum harvested at first and second milking, respectively. Receiver operating characteristics are presented in Figure 4.

In a prior study validating Brix readings with Jersey colostrum from primiparous and multiparous cows, $18 \%$ was deemed the most adequate threshold based on accuracy (Morrill et al., 2015). This proposed threshold for Jersey cows is lower than our suggested threshold. Moreover, it is also at the lower end of previous sug- gested thresholds for Holstein breeds, which ranged from 18\% (Morrill et al., 2012) to 22\% (Bielmann et al., 2010). However, in our study, when the best threshold for Brix reading was selected based on accuracy criterion, $18.0 \%$ at first milking (accuracy $=92.5 \%$ ) and $19.0 \%$ at second milking (accuracy $=79.4 \%$ ); results were similar to what Morrill et al. (2015) had previously proposed (Table 2). Nevertheless, results should be interpreted carefully as our data included only multiparous cows from a single dairy operation.

In our study the observed differences in Brix thresholds based on the diagnostic measurements chosen are most likely explained by the low number of colostrum samples that fail to meet the standards of quality at first milking. Accuracy is affected by the prevalence of poor colostrum quality; it increases as the prevalence decreases. Youden's index, a global measurement of a test performance based on maximizing the sensitivity and specificity, is not affected by the prevalence of the disease or proportion of poor quality colostrum samples. Thus, the implications of using different diagnostic test characteristics should be taken into account when trying to identify the optimum threshold for Brix readings.

Buczinski and Vandeweerd (2016) recently conducted a meta-analysis to evaluate the diagnostic accuracy of refractometry to predict colostrum quality. The study included 11 research studies with various breeds: Holsteins $(\mathrm{n}=4)$, Jerseys $(\mathrm{n}=1)$, mixed breeds $(\mathrm{n}=1)$, beef breeds $(\mathrm{n}=1)$, or nonidentified breeds $(\mathrm{n}=3)$. However, the low number of studies with known breeds other than Holstein did not allow the authors to explore the effect of breed on \%Brix reading. Results from this meta-analysis showed that Brix readings of $<18 \%$ were indicative of poor colostrum quality, whereas Brix readings of $\geq 22 \%$ were indicative of good colostrum quality. Buczinski and Vandeweerd (2016) suggested

Table 2. Diagnostic test characteristics for a digital Brix refractometer $(18,19,20,21$, and $22 \%$ thresholds) to predict colostrum that contains at least $50 \mathrm{~g} / \mathrm{L}$ of IgG measured by radial immunodiffusion ${ }^{1}$

\begin{tabular}{|c|c|c|c|c|c|c|c|}
\hline Milking & Brix threshold (\%) & Sensitivity (\%) & Specificity (\%) & PPV (\%) & $\operatorname{NPV}(\%)$ & Accuracy (\%) & Test high/low ${ }^{2}$ \\
\hline \multirow{3}{*}{ First } & 19 & 94.3 & 54.6 & 95.9 & 46.2 & 91.0 & $121 / 13$ \\
\hline & 20 & 93.5 & 72.7 & 97.5 & 50.0 & 91.8 & $118 / 16$ \\
\hline & 22 & 83.7 & 100.0 & 100.0 & 35.5 & 85.1 & $103 / 31$ \\
\hline \multirow[t]{3}{*}{ Second } & 18 & 86.2 & 66.7 & 65.8 & 86.7 & 75.0 & $38 / 30$ \\
\hline & 19 & 75.9 & 82.1 & 75.9 & 82.1 & 79.4 & $29 / 39$ \\
\hline & 22 & 31.0 & 100.0 & 100.0 & 57.4 & 70.6 & $9 / 59$ \\
\hline
\end{tabular}

${ }^{1}$ Colostrum was harvested from multiparous Jersey cows at first $(\mathrm{n}=134)$ and second $(\mathrm{n}=68)$ milking. PPV $=$ positive predictive value; NPV $=$ negative predictive value. Brix refractometer, Reichert Inc. (Depew, NY).

${ }^{2}$ Number of samples declared high or low (IgG $>50 \mathrm{~g} / \mathrm{L}$ ) based on \%Brix readings. 
that between 18 and $22 \%$ Brix colostrum management should be used to ensure that adequate colostrum volume is fed, to reduce the time between birth and first feeding so absorption is maximized (Michanek et al., 1989), to minimize microbial contamination to prevent bacterial sequestration of IgG (Johnson et al., 2007), or to incorporate colostrum supplements into the first feeding. Although classifying colostrum as good, poor, or suspect eliminates the uncertainty associated with readings slightly above or below a yes/no threshold, it will add complexity to the on-farm colostrum management program and may hinder colostrum protocol compliance on poorly managed dairies.

\section{CONCLUSIONS}

In this study, the prevalence of good colostrum quality $(>50 \mathrm{~g} / \mathrm{L}$ of $\mathrm{IgG})$ was elevated at first milking and moderate-to-low at second milking. The dam's lactation number, colostrum yield, and time of first milking relative to calving were associated with IgG concentration in colostrum from multiparous Jersey cows. Over half of the second milking colostrum samples from cows on their fourth or greater parity met industry standards for desirable $\operatorname{IgG}$ concentrations. This warrants routine evaluation of second milking colostrum in mature cows as an strategy to extend colostrum on dairies with limited supply. Readings of \%Brix can be used to rapidly estimate IgG concentration in Jersey colostrum harvested at first and at second milking from multiparous cows. The best \%Brix reading threshold to identify colostrum with $>50 \mathrm{IgG}$ g/L on first milking colostrum from multiparous Jerseys cows was $20.9 \%$ based on Youden's index criterion, challenging the previously proposed $18 \%$ Brix reading obtained from primiparous and multiparous cows. When accuracy was used as the selection criterion, results (18.0\% Brix) were the same as previous reports. Nevertheless, Youden's index is a more desirable selection criterion as it is not affected by the prevalence of poor quality colostrum.

\section{ACKNOWLEDGMENTS}

The authors appreciated the collaboration of Jer-ZBoyz Ranch (Pixley, CA) for allowing us to use their facilities, cows, and records.

\section{REFERENCES}

Beam, A. L., J. E. Lombard, C. A. Kopral, L. P. Garber, A. L. Winter, J. A. Hicks, and J. L. Schalter. 2009. Prevalence of failure of passive transfer of immunity in newborn heifer calves and associ- ated management practices on US dairy operations. J. Dairy Sci. 92:3973-3980. https://doi.org/10.3168/jds.2009-2225.

Bielmann, V., J. Gillan, N. R. Perkins, A. L. Skidmore, S. Godden, and K. E. Leslie. 2010. An evaluation of Brix refractometry instruments for measurement of colostrum quality in dairy cattle. J. Dairy Sci. 93:3713-3721. https://doi.org/10.3168/jds.2009-2943.

Buczinski, S., and J. M. Vandeweerd. 2016. Diagnostic accuracy of refractometry for assessing bovine colostrum quality: A systematic review and meta-analysis. J. Dairy Sci. 99:7381-7394. https://doi. org/10.3168/jds.2016-10955.

Cabral, R. G., C. E. Chapman, K. M. Aragona, E. Clark, M. Lunak, and P. S. Erickson. 2016. Predicting colostrum quality from performance in the previous lactation and environmental changes. J. Dairy Sci. 99:4048-4055. https://doi.org/10.3168/jds.2015-9868.

Conneely, M., D. P. Berry, R. Sayers, J. P. Murphy, I. Lorenz, M. L. Doherty, and E. Kennedy. 2013. Factors associated with the concentration of immunoglobulin $\mathrm{G}$ in the colostrum of dairy cows. Animal 7:1824-1832. http://dx.doi.org/https://doi.org/10.1017/ S1751731113001444.

DeNise, S. K., J. D. Robison, G. H. Scott, and D. V. Armstrong. 1989. Effects of passive immunity on subsequent production in dairy heifers. J. Dairy Sci. 72:552-554. https://doi.org/10.3168/ jds.S0022-0302(89)79140-2.

Faber, S. N., N. E. Faber, T. C. McCauley, and R. L. Ax. 2005. Effects of colostrum ingestion on lactational performance. Prof. Anim. Sci. 21:420-425.

Foley, J. A., and D. E. Otterby. 1978. Availability, storage, treatment, composition, and feeding value of surplus colostrum: A review. J. Dairy Sci. 61:1033-1060. https://doi.org/10.3168/jds.S00220302(78)83686-8.

Godden, S. 2008. Colostrum management for dairy calves. Vet. Clin. North Am. Food Anim. Pract. 24:19-39. https://doi.org/10.1016/j. cvfa.2007.10.005.

Gulliksen, S. M., K. I. Lie, L. Sølverød, and O. Østerås. 2008. Risk factors associated with colostrum quality in Norwegian dairy cows J. Dairy Sci. 91:704-712. https://doi.org/10.3168/jds.2007-0450.

Johnson, J. L., S. Godden, T. Molitor, T. Ames, and D. Hagman. 2007. Effects of feeding heat-treated colostrum on passive transfer of immune and nutritional parameters in neonatal dairy calves. J. Dairy Sci. 90:5189-5198. https://doi.org/10.3168/jds.2007-0219.

Maunsell, F. P., D. E. Morin, P. D. Constable, W. L. Hurley, and G. C. McCoy. 1999. Use of mammary gland and colostral characteristics for prediction of colostral IgG1 concentration and intramammary infection in Holstein cows. J. Am. Vet. Med. Assoc. 214:1817-1823.

Michanek, P., M. Ventorp, and B. Weström. 1989. Intestinal transmission of macromolecules in new-born dairy calves of different ages at first feeding. Res. Vet. Sci. 46:375-379.

Moore, M., J. W. Tyler, M. Chigerwe, M. E. Dawes, and J. R. Middleton. 2005. Effect of delayed colostrum collection on colostral IgG concentration in dairy cows. J. Am. Vet. Med. Assoc. 226:13751377 .

Morin, D. E., V. S. Nelson, E. D. Reid, D. W. Nagy, G. E. Dahl, and P. D. Constable. 2010. Effect of colostral volume, interval between calving and first milking, and photoperiod on colostral IgG concentrations in dairy cows. J. Am. Vet. Med. Assoc. 237:420-428. https://doi.org/10.2460/javma.237.4.420.

Morrill, K. M., E. Conrad, A. Lago, J. Campbell, J. D. Quigley, and H. Tyler. 2012. Nationwide evaluation of quality and composition of colostrum on dairy farms in the United States. J. Dairy Sci. 95:3997-4005. https://doi.org/10.3168/jds.2011-5174.

Morrill, K. M., K. E. Robertson, M. M. Spring, A. L. Robinson, and H. D. Tyler. 2015. Validating a refractometer to evaluate immunoglobulin G concentration in Jersey colostrum and the effect of multiple freeze-thaw cycles on evaluating colostrum quality. J. Dairy Sci. 98:595-601. https://doi.org/10.3168/jds.2014-8730.

Muller, L. D., and D. K. Ellinger. 1981. Colostral immunoglobulin concentrations among breeds of dairy cattle. J. Dairy Sci. 64:17271730. https://doi.org/10.3168/jds.S0022-0302(81)82754-3.

Pritchett, L. C., C. C. Gay, T. E. Besser, and D. D. Hancock. 1991. Management and production factors influencing immunoglobulin 
G1 concentration in colostrum from Holstein cows. J. Dairy Sci. 74:2336-2341. https://doi.org/10.3168/jds.S0022-0302(91)784063.

Quigley, J. D., A. Lago, C. Chapman, P. Erickson, and J. Polo. 2013. Evaluation of the Brix refractometer to estimate immunoglobulin G concentration in bovine colostrum. J. Dairy Sci. 96:1148-1155. https://doi.org/10.3168/jds.2012-5823.

Quigley, J. D., K. R. Martin, and H. H. Dowlen. 1995. Concentrations of trypsin inhibitor and immunoglobulins in colostrum of Jersey cows. J. Dairy Sci. 78:1573-1577. https://doi.org/10.3168/ jds.S0022-0302(95)76780-7.

Quigley, J. D., 3rd, K. R. Martin, H. H. Dowlen, L. B. Wallis, and K. Lamar. 1994. Immunoglobulin concentration, specific gravity, and nitrogen fractions of colostrum from Jersey cattle. J. Dairy Sci 77:264-269. https://doi.org/10.3168/jds.S0022-0302(94)76950-2.

Raboisson, D., P. Trillat, and C. Cahuzac. 2016. Failure of passive immune transfer in calves: A meta-analysis on the consequences and assessment of the economic impact. PLoS One 11:e0150452 http:// dx.doi.org/https://doi.org/10.1371/journal.pone.0150452.

Tyler, J. W., B. J. Steevens, D. E. Hostetler, J. M. Holle, and J. L. Denbigh Jr. 1999. Colostral immunoglobulin concentrations in Holstein and Guernsey cows. Am. J. Vet. Res. 60:1136-1139.

Youden, W. J. 1950. Index for rating diagnostic tests. Cancer 3:32-35. 